https://helda.helsinki.fi

\title{
Venäläisterroristien suomalaiset tukijoukot ja kansojen moraalinen vastuu
}

\section{Ikonen, Susan}

2020

Ikonen , S 2020 , ' Venäläisterroristien suomalaiset tukijoukot ja kansojen moraalinen vastuu

' , Idäntutkimus, Vuosikerta. 2020 , Nro 3-4, Sivut 60-63 .

http://hdl.handle.net/10138/340495

Downloaded from Helda, University of Helsinki institutional repository.

This is an electronic reprint of the original article.

This reprint may differ from the original in pagination and typographic detail.

Please cite the original version. 
paikoitellen luvut saattavat jäädä muutaman sivun mittaisiksi pintaraapaisuiksi tai jonkin kuriositeetin esittelyksi. Kuitenkin sen minkä teos häviää syvällisyydessään, se voittaa omakohtaisuudessaan, värikkäissä paikallisten henkilökuvissa ja haastatteluiden kautta avautuvissa keskusteluissa. Kunnanjohtajien, alkuperäiskansojen edustajien, eläintensuojelijoiden ja mam- mutinluiden etsijöiden haastattelut valottavat Siperian arkea lukuisista eri näkökulmista ja osoittavat myös käytännössä sen, ettei Siperia ole monoliitti, vaan monenlaisista ilmiöistä ja ihmisryhmistä koostuva heterogeeninen kokonaisuus.

Eeva Kuikka

\section{Venäläisterroristien suomalaiset tukijoukot ja kansojen moraalinen vastuu}

\section{Erkki Vettenniemi: Suomi terrorin tukikohta- na. Kuinka Lenin tovereineen tuhosi Venäjän suomalaisten suosiollisella avustuksella. Helsinki: SKS, 2019. 304 s. ISBN: 978-951- 858-049-5}

YTT, historioitsija ja tietokirjailija Erkki Vettenniemi käsittelee teoksessaan Suomen ja Venäjän yhteisen historian vaiheita 1900-luvun alkuvuosikymmeniltä, esittelee myöhempiä arvioita noista vaiheista sekä antaa lopuksi voimakkaan mutta epäselvästi esitetyn moraalisen tuomion. Teos sivistää ja viihdyttää mutta myös hämmentää lukijaansa. Teoksesta näkyy merkittävä tutkimuksellinen panos aihepiiriin, mutta lopulta on epäselvää, missä määrin tämä SKS:n julkaisema teos täyttää tietokirjan määritelmän. Aiemmissa teoksesta kirjoitetuissa arvioissa (mm. HS 7.11.2019 ja lukuisat blogit) teosta on luonnehdittu pamfletiksi ja villiintyväksi spekulaatioksi, mitkä arviot puoltavat paikkaansa. Esitän tässä oman luentani siitä, mitä Vettenniemi teoksellaan mahdollisesti haluaa sanoa, sekä arvioni siitä, miksi sanoma saattaa jäädä lukijalle sameaksi ja miksi teosta kannattaa pitää pamflettina tietokirjan sijaan.

Vettenniemen monella tapaa ansiokas ja erinomaisen mukaansatempaavasti kirjoitettu teos käsittelee vuosia 1905-08 sekä vuotta 1917 - aikaa, jolloin yhtäältä suomalaisten (porvarillisten) aktivistien ja kulttuurieliitin piireissä ja toisaalta sosialistien parissa tuettiin vahvasti venäläisiä vallankumouksellisia, myös terroristeja. Tsaarinvaltaa vastustaneet vallankumousryhmittymät löysivät Pietarin läheisyydessä olevasta Suomesta moraalista ja konkreettista tukea suunnitelmilleen. Etenkin teema "Lenin Suomessa" on tunnettu, mutta Vettenniemi laajentaa kuvaa suomalaisten yhteyksistä bolshevikkien ohella muihin terroristeihin. Teoksen kiistattomaksi ansioksi voi myös laskea lopun tiiviin katsauksen suomalaisten punapakolaisten ja pietarilaisbolševikkien osuudesta Venäjän sisällissodan aikaisiin väkivaltaisuuksiin.

Tämä käsittely on teoksen näennäinen ydin, mutta teoksen varsinainen motiivi - jonka teoksen alaotsikko paljastaa - on lähtöisin Aleksandr Solženitsynin moraalisista näkemyksistä neuvostoajan terrorista ja kansojen syyllisyydestä. Vettenniemen kertoma tarina suomalaisten tuesta Venäjän vallankumouksellisille ei sinällään ole uusi, mutta sen kontekstualisoiminen yhtäältä Solženitsynin näkökulmaan kansojen moraalisesta vastuusta, toisaalta holokaustia koskeviin syyllisyysnäkökulmien politisoitumiseen 2000-luvulla, muodostavat sen tulkintakehikon, jossa suomalaisten osallisuutta venäläisterroristien toimiin esitellään ja arvioidaan. Ongelmallista on se, että tulkintakehys avataan lukijalle vasta teoksen lopussa, varsinaisten käsittelylukujen jälkeen.

Varsinaiset kolme käsittelylukua etenevät kronologisesti. Ensimmäinen osa "Rauhan tyyssija" kuvaa, kuinka Suomen suuriruhtinaskunnan alamaiset eri tavoin avustivat venäläisiä vallankumouksellisia terroristeja vuosina 190507. Venäläiset löysivät tuolloin turvapaikan pääkaupungin liepeiltä, eteläisen Suomen ja etenkin Karjalankannaksen paikkakunnilta, joissa terrori-iskujen, murhien ja pankkiryöstöjen suunnittelijoita ja toteuttajia piiloteltiin. Suomen alueella he saivat rauhassa kehitellä tappavia pommeja, verkostoitua ja kirjoittaa ideologisia tekstejään sekä puhtaasti lomailla. Terroristeilla tarkoitetaan tässä teoksessa kaikkia väkivaltaan turvautuneita ja sitä ideologiassaan mukanaan pitäneitä vallankumousryhmittymiä. Teoksen päähenkilöitä ovat - bolševikkien ohella - sosialistivallankumoukselliset (eserrät) sekä maksimalistit, jotka olivat irrottautuneet eserreistä ja pyrkivät "maksimaaliseen muutokseen”. Noina vuosina eserrät olivat vähintään 
yhtä merkittäviä toimijoita kuin bolshevikitkin. Teos valaisee mukaansatempaavasti eri vallankumousryhmittymien keskinäistä yhteistyötä ja taloudellisia suhteita: bolševikit muun muassa myivät kehittelemiään pommeja eserreille.

Toinen luku"Terrorismin taltuttaja" käsittelee Pjotr Stolypiniä, Suomea ja sitä, miten maksimalistien Helsingissä punoma murhayritys osaltaan vaikutti siihen, että Venäjän poliittinen johto tajusi Suomen erivapauksien mahdollistaneen suuriruhtinaskunnan muodostumisen ruutitynnyriksi ja tukikohdaksi vallankumouksellisille. Siinä missä ensimmäisen luvun ansiona voi pitää eri terroristiryhmien monipuolista esittelyä, toisen luvun ehdoton anti on se, miten tekijä asemoi Suomen tilanteen yleisvaltakunnalliseen kontekstiinsa; suomalaisessa kansallisessa historianarratiivissa ei ole juuri herunut ymmärrystä Stolypinille. Kolmannessa, vuoden 1917 myllerryksiin keskittyvässä luvussa 'Leninin lumoissa" Vettenniemi tuo hyvin esiin sen, miten bolshevikit olivat kevään vallankumouksen myötä syntyneistä ryhmistä aidosti ainoa, jonka julkilausuttuun politiikkaan edes jossain määrin kuului itsenäisyyden myöntäminen Suomelle. Kaikki muut poliittiset ryhmät joko vastustivat tai empivät tämän suomalaisille keskeisen kysymyksen äärellä.

Vettenniemen teksti on tapahtumien imuun intoutuessaan parhaimmillaan kuin jännitysromaani. Vaikuttaa siltä, että edes Leninin ja hänen verisen terrorinsa kovinkaan kriitikko ei voi olla tempautumatta dramaattisten tapahtumien käänteisiin (esimerkkinä klassinen teema "Lenin pakenemassa murtuvalla jäällä"). Parhaimmillaan Vettenniemi paitsi luo sujuvan tarinan myös analysoi lähteitään. Valitettavasti analyyttinen ote usein puuttuu silloin, kun tekijä ryhtyy spekuloimaan moraalisesti (esimerkiksi Mauno Koiviston antikristus-pohdinnat, s. 147). Teoksen erikoispiirre on, että Vettenniemi käyttää viestinsä läpiviennissä tiettyjä auktoriteetteja (etenkin Koiviston mutta myös Paasikiven arvioita) ikään kuin perustelemaan omia vaihtelevia spekulaatioitaan. Teos siis kuljettaa mukanaan myös myöhempiä merkityksenantoja tutkimuksen kohteena olevalle aikakaudelle. Oman osansa kritiikistä esimerkiksi saa 1970-luvun Suomessakin kukoistanut Lenin-kultti. Teoksen muutoin kronologisesti etenevää tarinaa katkovat sivun mittaiset "tietolaatikot", joissa tekijä antaa ajatustensa laukata villistikin. Parhaimmillaan teos sisältää tutkimuksellisesti perusteltua kontrafaktuaalista spekulaatiota, joka tarjoaa uusia näkökulmia historian käännekohtiin. Pahimmillaan se on pelkkää jossittelevaa jaarittelua ilman mitään tiedollista, saati analyyttistä arvoa

Teoksen taustakehikon keskeisenä teemana voi pitää "punaisen fasismin" tai "punaisen holokaustin" rinnastamista holokaustiin ja siihen liittyviin syyllisyyskysymyksiin. Tässä ongelmana on mielestäni Solženitsynin käyttäminen ylimpänä auktoriteettina - ja ennen muuta se mutka, jota kautta kysymys suomalaisten syyllisyydestä nostetaan esiin. Lukija saa sangen perinpohjaisen yllätyksen teoksen lopussa alaluvussa "Juutalainen juoni?", jossa Suomen ja suomalaisten syyllisyyskysymystä vaaditaan tarkasteltavaksi moraalisessa kontekstissa, jonka pohjana on Aleksandr Solženitsynin näkemykset juutalaisista (toki myös venäläisistä, mutta juutalaiset korostuvat teoksen käsittelyssä). Ongelmallista on se, että Vettenniemi ei avaa tarvittavan selkeästi Solženitsynin kantaa juutalaisiin. Mukana on myös vallankumousta seurannutta aikalaisymmärrystä bolševismista juutalaisena luomuksena, mutta samaan aikaan tekijän oma asennoituminen jää lukijalle epäselväksi. Nämä epäselvyydet vaikeuttavat teoksen argumentaation ymmärtämistä.

Sanoman sisäistämistä vaikeuttaa siis se rakenteellinen valinta, että lukijaa ei valmistella johdannossa lainkaan solzhenitsyniläisen eetoksen käyttöön pääargumentin kehystämisessä: kysymyksessä kansan kollektiivisesta syyllisyydestä. Pääargumentti esitetään vasta teoksen lopussa. Niin ikään rakenteellis-metodologisena ongelmana voi pitää sitä, että tekijä ei esittele eikä erittele lähteitään eikä perustele, millä kriteereillä on valinnut yhtäältä lähteet, toisaalta teoksen viitekehyksen tai siinä käytetyt auktoriteetit. Myös käytetty viittauskäytäntö ei aina auta selventämään, mitkä ovat Vettenniemen omia väitteitä ja mitkä argumentit pohjautuvat aiempaan tutkimukseen. Liioin sitä metodologista valintaa, ettei mittavassa lähde- ja kirjallisuusluettelossa ole yhtäkään venäjänkielistä lähdettä tai teosta, ei lukijalle kerrota tai perustella. Tämä johtaa siihen, ettei lukija saa käsiinsä avaimia teokseen. Tavanomaisen johdannon sijaan lukija temmataan tapahtumien syövereihin sekä tapahtumille myöhemmin annettuihin merkityksiin.

Lukija saa siis yllättyä teoksen lopussa. Teoksen johdannon ja loppusanojen välinen yhteys löytyy vuoden 2000 tapauksesta, jossa silloinen pääministeri Paavo Lipponen pyysi suomalaisten puolesta anteeksi juutalaisyhteisöltä 1942 tapahtunutta juutalaisten luovuttamista. Vettenniemen mukaan tämä oli osoitus tunnustetusta kollektiivisesta vastuusta, mutta hänen mielestään "Venäjän kohdalla sille löytyy paremmat perusteet kuin vuonna 1942 luovu- 
tettujen juutalaisten suhteen". Perusteluiksi annetaan ainoastaan tekijän toteamus (s. 255): "Uhrien kokonaismäärän perusteella juutalaisten joukkotuhoa olisi luvatonta nimetä historian synkimmäksi hetkeksi. Vuonna 1917 vauhtiin päässeen punaisen holokaustin ruumiskasa on suunnattomasti korkeampi ja sitä siis suomalaiset ennestään korottivat." Tässä kohtaa herää lukijan mielessä kysymys: eikö vertailulle todella ole muita kriteerejä kuin ruumiskasan koko? Kirjassa sivuutetaan täysin se, että on olemassa paljon natsismia ja neuvostoterroria vertailevaa totalitarismin tutkimusta. Holokaustin vähättely ei ole edellytys "punaisen holokaustin" perusteelliselle tutkimiselle.

Pidän ongelmallisena myös sitä, että Vettenniemi kuittaa Stalinin loppuaikoina institutionalisoituneen neuvostolaisen antisemitismin ongelmat toteamalla ykskantaan, miten Stalinin kaudella yleistyi "käsitys juutalaisista ensin tsarismin, sitten kommunismin uhreina, ikään kuin bolshevikkien etujoukoissa ei olisi ollut ainuttakaan juutalaista" (s. 245). Tekijä toteaa myös Solženitsynin viritelleen 2000-luvun alussa "rauhallista puhetta araksi koetusta juutalaisaiheesta" (s. 245). Oletettavasti kuitenkaan Solženitsynin kansallisuusajattelu ei ole jäänyt vaille kritiikkiä. Mikäli haluttaisiin käyttää Solženitsynin näkemystä juutalaisten kollektiivisesta syyllisyydestä pohjana sille moraaliselle vaatimukselle, että suomalaiset tunnustaisivat kollektiivisen syyllisyyden osallisuudesta 1900-luvun alun terrorin tukemiseen, Leninin valtaannousuun ja kaikkeen sitä seuranneeseen verenvuodatukseen, pitäisi Solženitsynin kansallisuusajattelua myös kriittisesti analysoida.

Suomalaisten 1900-luvun toimijoiden päämäärät ovat olleet suhteellisen selkeät, minkä myös Vettenniemi tuo teoksessa esiin. Tsaarinvalta nähtiin taantumuksellisena sortokoneistona, ja suomalaisilla oli omat kansallisvaltiolliset intressinsä, jonka nojalla he toimivat. Vettenniemi toteaa Solženitsynin linjanneen kansakunnan olevan "syyllisyyden yhteisö” (s. 245). Hän puurouttaa oman pohdintansa toteamalla, että suomalaisten syyllisyydestä "ei sentään sovi puhua" ja jatkaa: "Ikään kuin suomalaiset olisivat olleet Leninin ainoita tai altteimpia avustajia!’. Hän jatkaa, että myös Sveitsi, Italia ja etenkin Saksa rahoituksineen olivat Leninin avustajia. Myös suomalaisten terroristeille antaman avun kontekstualisointi tapahtuu teoksessa kuin varkain: tekijä toteaa (s. 112), ettei Suomessa lopulta kuitenkaan piilotellut kuin murto-osa kaikista vallankumouksellisista eivätkä Suomesta käsin tehdyt iskut muodostaneet suurinta osaa terrorin kokonaistuhoista.
Vettenniemen teos ravistelee ajatuksia ja herättää enemmän kysymyksiä kuin tarjoaa vastauksia. Nostan vielä esiin muutaman mieltä vaivaamaan jääneen kysymyksen. Keskeisin niistä koskee vertailun mielekkyyttä koskien suomalaisten ja juutalaisten vastuuta bolshevismin synnystä ja seurauksista. Mikäli Suomea ja suomalaisia - joiden pyrkimyksenä oli valtiollinen autonomia tai itsenäisyys - halutaan verrata muiden kansojen edustajiin, olisi sopivampi vertailukohta Georgia ja georgialaiset. Heidän alueensa liitettiin keisarikuntaan samoihin aikoihin Suomen kanssa, georgialaisia toimijoita oli mukana yleisvenäläisessä sosialistisessa liikkeessä, ja Georgia itsenäistyi Suomen kanssa samoihin aikoihin, joskin vain muutamaksi vuodeksi. Mitä tulee vankileirien saaristoon, toki Lenin ja Trotski aloittivat valtiojohtoisen väkivallan, mutta tämä prosessi ("punainen holokausti”) äityi pahimmilleen kuitenkin georgialaisen johtajan alaisuudessa.

Onkin kysyttävä, onko tässä teoksessa muuta pohjaa juutalaisten esiin nostamiselle kuin Solženitsynin kirjoitukset, vai tarvitaanko holokausti (ja sitä koskeva jaettu syyllisyys) mukaan osoittamaan, että samanlaista moraalista otetta vaaditaan suhteessa punaiseen holokaustiin? Päänsärkyä aiheutuu siitä, että lukijan ajatusketju voi lähteä villille laukalle johtaen aina siihen kysymykseen asti, loivennetaanko juutalaisten kärsimyksiä holokaustissa toteamalla heidän olleen syyllisiä bolshevismin rikoksiin. On korostettava, ettei teos itsessään tee tätä yhteyttä (joka perinteisesti tunnetaan judeo-bolševistisena salaliittona). Kuitenkin lukijan ajatuksia ravistellaan siihen malliin, että tuollainenkin yllättävä johtopäätös on mahdollista tehdä. Nämä pohdinnat liikkuvat kuitenkin aivan muissa sfääreissä kuin siinä, missä määrin suomalaiset 1900-luvun alussa auttoivat venäläisvallankumouksellisia.

Vettenniemen teos ei siis saa vakuuttuneeksi siitä, että kysymystä juutalaisten asemasta uhreina tai syyllisinä kannattaisi ottaa pohjaksi mahdolliselle suomalaiselle kansalliselle itsetutkiskelulle, johon teos haluaa lukijansa johdattaa. Vastaavasti herää kysymys, missä määrin Solženitsynin neuvostoterrorin synkeänä perintönä syntyneet kansallisuuksia koskeneet ajatukset ylipäätään ovat tai voisivat olla relevantti tutkimuksellinen viitekehys 2020-luvun tutkimuksessa. Vaikutelmani Vettenniemen teoksen perusteella on, että Solženitsynin mukaan tuomisella keskustelu siirtyy väistämättä historian- ja moraalifilosofian puolelle, kauemmas varsinaisesta historiantutkimuksesta. Vettenniemi yrittää yhdistää nämä eri aspektit 
sekä kontrafaktuaalisen spekuloinnin, mutta nähdäkseni ei aivan onnistu pyrkimyksissään. Kirjassa on tutkimukseen perustuvia yleistajuisia historiaosia sekä pamflettimaisia, kantaa ottavia ja moralisoivia osia. Lukija ei kuitenkaan aina tiedä, kumpaa lukee. Tietokirjaosuuksissa teos onnistuu hyvin, mutta pamflettimaisuus tulee mukaan varkain, eikä sen lähtökohtia avata ja valintoja perustella mitenkään, jolloin lukijan on vaikea ottaa itse kantaa esitettyihin näkemyksiin. Tämä sisällöllis-rakenteellinen heikkous syö kirjan arvoa tietokirjana, mikä on valitettavaa.

Teos ottaa myös kantaa myöhempiin merkityksenantoihin. Vettenniemi on tehnyt erinomaista työtä asettaessaan Stolypinin ajan suomalaisten ja suomalaisiin kohdistuneet toimet yleisvaltakunnallisiin konteksteihinsa. Samaa periaatetta tekijä olisi voinut noudattaa myös käsitellessään 1970-luvun virallisen Suomen suhtautumista Leniniin. Tekijä halveksuu sangen avoimesti aikakauden suomalaisten neuvostomyönteisyyttä ja Leninin roolin ylikorostamista (ilmeisen ironisesti teoksen kuvituksena on käytetty sangen paljon kuvia 1976 valmistuneesta suomalais-neuvostoliittolaisesta Luottamuselokuvasta). Mikäli tässäkin tapauksessa olisi huomioitu "yleisvaltakunnallinen konteksti", myös suomalaisten Lenin-into olisi tullut ymmärrettäväksi: vallankumouksen 50-vuotisjuhlista alkaen Lenin-kulttia tietoisesti kasvatettiin Neuvostoliitossa (mikä oli yksi neuvostovallan metodi stalinismin käsittelyssä tai käsittelemättä jättämisessä. Tämä on toki kokonaan oma tutkimusaiheensa). "Yleisliittolainen trendi" ei voinut olla heijastumatta myös Suomeen, niin ulkokuin sisäpoliittisestikin. Teoksen yleistä tulkintaa vasten voikin kysyä, lisääkö tämä neuvostolaisen Lenin-kultin myötäily todella suomalaisten oletettua "syyllisyyttä" sen enempää kuin aikakauden neuvostotoimijoiden osalta. Vettenniemi ennustaa, että Suomessa on edessä jonkinlainen tilinteko neuvostomyötäilyn suhteen, ja kunhan tuo tutkimus täyttää akateemiset kriteerit, sitä voi tervehtiä ilolla. On todennäköistä, että siinä kohtaa Vettenniemen teos nostetaan esiin, ainakin viitattaessa vallankumousta edeltäviin vuosiin.

Edellä esittämästäni kritiikistä huolimatta totean Vettenniemen teoksen olevan ehdottomasti tutustumisen arvoinen kirja. Sen tärkein sisältö on tutkimukseen nojaava, sangen koherentti kuvaus suomalaisten avunannon muodoista Venäjän vallankumouksellisessa liikehdinnässä. Teos myös antaa kiinnostavia näkökulmia kansallisen historiankirjoituksemme pohdintaan. Teoksen perusideasta - solzhenitsyniläisen kansallisuusajattelun soveltamisesta suomalaisten oletettuun syyllisyyteen Venäjän vallankumoukseen ja sen seurauksiin - ja sen pohjalta annetun viitekehyksen toimivuudesta kannattanee jokaisen lukijan muodostaa oma käsityksensä.

Susan Ikonen

\section{Uutta tietoa Suomen ja Neuvostoliiton kulttuurisuhteista}

\section{Simo Mikkonen: "Te olette valloittaneet meidät!” Taide Suomen ja Neuvostoliiton suhteissa 1944-1960, Helsinki: Suomalaisen Kirjallisuuden Seura, 2019. 332 s. ISBN 978- 951-858-129-4.}

Ennen kuin ehdin avata historioitsija Simo Mikkosen uutta teosta, "Te olette valloittaneet meidät!" Taide Suomen ja Neuvostoliiton suhteissa 1944-1960, sai kirjan yläotsikko minut mietteliääksi. Valloittaa-sana yhdistyi mielessäni yksioikoisesti sotilaalliseen miehitykseen, ja sai pohtimaan, millä tavalla tämä näkökulma yhdistyisi taiteeseen. Paljon johdantoa pidemmälle ei kuitenkaan tarvinnut lukea, kun otsikko sai selityksensä. Neuvostoliiton kulttuuridelegaatio konsertoi Kansallisteatterissa kutsuvierasnäytännössä Suomen yhteiskunnan eliitille tammikuussa 1945. Konsertin kirkkaimpana tähtenä esiintyi maineikas Puna-armeijan kuoro, jonka jäseniä Hella Wuolijoki kiirehti konsertin päätyttyä kukittamaan. Vanhojen Suomi-filmien ystävänä pystyn sieluni silmin kuvittelemaan virolaisaksentilla suomea puhuneen Wuolijoen ylistämässä konserttia itänaapurin kulttuuriväelle. "Te olette valloittaneet, te olette valloittaneet meidät!"

Wuolijoen ylistyslaulun voi tulkita monella tapaa. Yhtäältä se kertoo Neuvostoliiton taiteen arvostuksesta ja ylipäänsä mahdollisuudesta nauttia korkealaatuisesta taiteesta pitkien sotavuosien jälkeen. Toisaalta hänen sanoistaan voi lukea ennustuksen Suomen ja Neuvostoliiton kulttuurisuhteiden tulevaisuudesta, joka haltioituneen ihastelun ohella sai kielteisempiäkin sävyjä. Vaikka Neuvostoliitto ei valloittanut Suomea sotilaallisesti, se onnistui valloittamaan ainakin osan suomalaisten mielistä. Teoksen otsikkoa voi näin ollen pitää varsin nerokkaa- 